\section{䊅}

\section{锰}

1)バリウムカプセル笪下法を利用して，カプ セル停留部位と知営部位とをレ楾透視下に対比 して筧察した。

2)垻部食道領域の知覚は略正確であるが，胸 部食道領域以下の知覚は胸骨上䆚に感じこと が多い。

3)一般に食道知喾には規則性は認め藉い。従 つて異物介在部位を知覚によつて推湘すること
は極めて危険である。

(恩助後藤教授の御校閴を澡謝する)

\section{主 要 文 献}

1) 睠木: 日本臨床 9 巻 325 (昭26)

2) 木村: 臨床 3 巻 646 (昭25)

3）幻戸他：第 4 回日本気管食道科学会給会にてロ 演（気食会報㫮載予定）

4) 和気：能本医学会誌 25 巻 317 (昭26)

5）大場：日外宝函 22巻 7 (昭28)

\title{
弛緩性 食道廐症例
}

\section{1 楮}

百

最近私は，照下不能を主訴とせる多発性瞪神 释根炎の一例を程験した。その侵されし瞒神经 は，主として V VIXXNXの広きに渡り，本邦 にてこの様な文献例む珍らしいので報告する。

\section{2 症}

型者 23才。会社員初診昭和 28 年 7 月 18 日。同日入院

主訴 摸食哭下不能

家斿麾 特記すべきすのはない。

既往原 梅毒, チフテリーの既往歴はない が，18 才の時, 肋膜炎に䍜患せるす完全治檍 した。患者は生来健康ではあつたが，家人の言 によれば，多少神経質の由。

現病歴 入院の䄪 1 ヶ年程前より劇務が続き 過労気味で，時々頭痛を訴えていた。入院 10 日前に $39^{\circ} \mathrm{C}$ の発熱ありて, 医師により流行性 感园の治療を受け 2 日にして下熱す。その後 2 日して，夕食時に突然に提食不能となり，首を 前後に振り振り食事すれば，少量は通過した。

\footnotetext{
* 大阪大学医学部耳留咽㫿科教室 (主任山川教授)
}

然し湯荣は楽に飲み込めた由。悪心，嘔吐，㖽 声, 呼吸困難などは訴えていない。次の翌朝食 よりは, 㩒食全く不能となり, 湯茶は勿論, 唾 液すらも喏下不能となつた。全身僚念感强く， そのまま林についてしまつた。ところが頸の運 動が思 万様にならず, 頸を迴すことも, 頭を持 ちあげることも出来ず，両手にて頭をかかえて 颂の運動を助ける状態で，で両手を放すと，ド スンと頭が落下する。既ち頸定まらず。直ちに 某大学病院受診しチフテリ一後麻㾝と云われ， 血清注射など受くるも快方に向わず。食道直连 鏡検本にて, 食道入口部以下, 食道壁は营白弛 移し，無抵抗に直達鏡は入り，蝶動諗め難しと の所見を得て，山川臨床に入院したものであ る。入院まで，陆腔注入，リンゲル注射などを してもらつていた由。

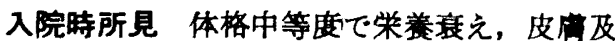
び可視粘膜は少し全血様，脈博は緊張良く規則 正しい。胸腹部搭器に著变を器めない。病的反 射なく，皮届反射異常なきも，滕蓝琏反射六進 し，特に左側の方がり高い。皮局知觉左側 多少鋭敏である。瞹孔対光反射正常で，眼底及 び視野に異常なきる，睡孔左右不同症（右 3.5 $\mathrm{mm}$, 左 $4.0 \mathrm{~mm}$ ) がある。眼球運動正常で複視 
はない。左上下口唇に帯状包疹を諗める。又, 左側末梢性顔面神程麻疸を認める。即ち，左額 に破寄らず象眼がある。Bell 氏症状陽性。左鼻 唇溝消失し，左口角下垂し流涎を認める。睡液 分泌は減少し，粘稠である。舌運動障碍され て, 左に傾く。為に舌音 (ラ行) 唇音 (パ行) 発音不能。然し口蓄運動は正常である。㖽声, 呼吸困難などすなく，声带連動も正常である。

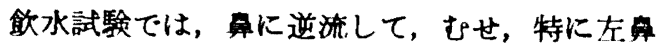
腔より多く流出する。検榃成紸として，血浓所 見は，赤血球 423 万，白血球 $9600 \mathrm{Hb} 90 \%$ 赤 血球疒降速度は 30 秒 181 時䦥 58 で元進し， 多少白血球增多症を邫める。尿所見は，蛋白

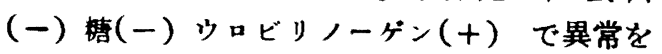

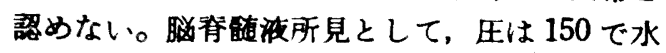
様透明であるが，湅胞数は ${ }^{148} / 3$ Lympho/poly $2: 1$ Nonne-Apelt 反底 $(+)$ 蛋白 2 分㗲。 即ち，淋巴球の増加あるる，Dissociation albuminocytologique はない。握力計は左右共 5 10。穽時体温 $37.3^{\circ} \mathrm{C}$

㳗过及ひ処贯 入院当日夜に $39.5^{\circ} \mathrm{C}$ の発熱 あり。鼓弱甚だしく，三食とも腔注入を行 5。口若に带状包疹わあるので,オーレオマ1 シン毎回 $250 \mathrm{mg}$ 注入す。勿論ぶど 糖、ビタ ミン $\mathrm{B}_{1}, \mathrm{C}$ 等の注射む行つた。熱発は当日のみ で下繁す。入院後 3 日目には左頵面神释麻痐は 益々著明となると同時に，右顔面神程麻庫す裴 われ, 為に鬼眼著明となり, 活眼賖は釉 $1 \mathrm{~mm}$ 閣く。眼球通動は心常で复視などなし。唤觉，

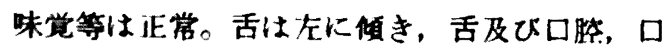
真，咽頚などの粘膜は大側が知觉過较である。 阔口すれば卜影は著明に左に垻き，咬能反射は

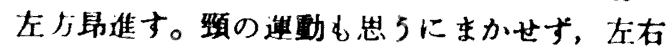

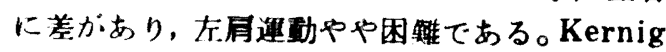
氏症状(一)，Babinski 氏症状(一)。坐骨神経 及ひ上膊神释黄性有著明。脈博は60 で規则 正しい。入院前後とも悪心嘔吐はない。オーレ オマイシン連続一週間投与の後へルペス消失 し，麻㾝やや固定の感あり。㮸つてその後は， (入院 8 日目より) $\mathrm{VB}_{1}$ 高単位潦法 $(100 \mathrm{mg}$ 筋 注，50 mg 静注）を央施し，且つ週 2 回，面接 にルンパールにて VB, $5 \mathrm{mg}$ 及オピンート注入

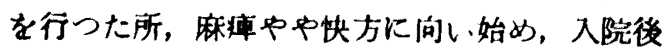

18 日目（発病以来 25 日目）より，流動食が 通り始めた。この時の患者の喜びは笋舌に尽し 難い。最初は下影を左肩につけると入り易く, 湯茶なれば胃に落下寸る音を閥いたと云 5。

(Dysphagia sonora)これにて無腔注入は中 止す。然し, その後は症状遅々として変化せ ず。ルンバール10 回目の翌日（入院後 38 日 発症後 45 日）上り固形食通過可能となる。顔 面神経麻㾝も㱠と消失し, 体重も増加に向い, 入院後 48 日にして，元気になり退院した。

\section{3 考按}

患者の口述や家人の言によれば，原因として 考え当るむのはないか，当時患家の近くに，農 蒋中毒 (ホリドール) ありたるる，これは迷走 神释制戟に㗢くすので，原因として考えられな い。食道麻瘒を来す原因として；ヂフテリー， 鉛中毒, 酒精中毒, 梅毒, チフス，腸詰中毒等 があるが，いずれる否定された。此の中で，チ フテリーが軗く柽過した場合は一寸分り難い が，原因とは思われぬ。鑑别すべき疾患とし

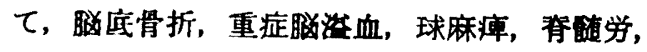
多発性硬化症，媢炎，進行性能麻㾝などがある が，いすれも特有の症候で鑑別は容易である。 本腎者の症状よりみて，口唇のへルペス，瞒脊

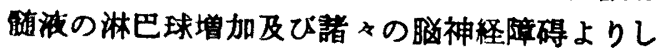
て，䀡橋より延随にかけて，向神経性ビールス の侵入ありたるるのと考える。V VIIXXXXIの 核は㮸橋より延镇にあり。この部に何か一過性 の炎症性変化があつたに違いない。初診時に は，小児麻庫 (Landry型)を5たがい，予後 を策じたのであるが，経過と共に否定された。 特に興味あることは，迷走神程の中，食道を支 配する神释が主として侵されたことである。佁 顔面神释が侵されているのに，聴神释は全く所 見なく，聴力は勿論前庭機能は正常であつた。 症状より見て，これら眑神経核の左方核に主と して強く㑬いたすのと哮え。

\section{4 楛 蛅}

以上， 23 才すに於て，乫然に排食不能とな りたる多発性脂神経根炎の一例を報告した。種 々治療の結果, 発症より流動食可能まで 25 日 
気食会報一5巻

固形食可能まで 45 日を要した症例である。

（稿を終るにあたり，恩師山川教授の御指導を 深く感謝致します。)
2) 西
日耳鼻
35巻 149頁
3) 柳原, 高楖 耳舆臨 43巻 3号,
4) 兴健科書
5）山川 診断治療 38 巻 1号

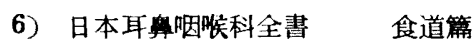

文

献

1）楖原, 宫内 耳監虽 45巻 367頁

\section{気管内扱管による呼吸循環系の変動}

挿管とい5事は気管内麻酷に於いてて現在晋通 に行われる操作であるが, 我ふが今日迄行つた 麻酔例の5 万，導入麻酥及び择管の後に呼吸の 抑制，或は停止，チアノーゼ，血圧の下降， Shock, Cardiac arrest, 等の臨床症状を極め て低率ではあるが経験しているので，抻管操作 自体が呼吸循程系に如何なる変化を与えるかに ついて検索を試みた。

検查方法としては, 胸部手術患者に気管内麻 醉を施し，麻醉・手術前より予め心睚カテーテ ルを肺動脈に挿入しておいて, 手術経過中種々 の時期に於ける肺動脈圧, 及ひ脈波, 血液ガス $\mathrm{pH}$ ，末梢血压を測定し，更に呼吸気の分祈， オキシメーターによる動脈血酸素飽和度の測定 を行つたっこの成績の詳細についてては本年の胸 部外科学会で本学笹本助教授より報告された が，ここでは挿管による変化についてのみ述へ る。又導入麻酔はサイクロプロペイン, ペント タール・クラレ, サイクロプロペイン・クラレ, ペントタール・笑気, ペントタール・笑気・ エーテル，等のオ法で行つたか，前述の諸検歪 は萃入麻醉前, 導入麻醉を行つたが末だ挿管す る前, 㨉管直後と別々に行つたので麻醉剂によ る影慜は一応別けて考兵る事にする。

$\begin{array}{ccccc}* \text { 天野道之助 } & \text { 鈴 } & \text { 達 } & \text { 雄 } \\ \text { 河 端武親 金井 } & \text { 真 } \\ \text { ** 原 川 信 次 片 桐 鎮 } & \text { 夫 } \\ \text { 和 田 知 雄 佐 藤 } & \text { 孝 }\end{array}$

成

図表 [1] 分時换気量は挿管直後一般に減少 する。之は㨉管の物理的刺戟に対する生体防䠗 図表 1

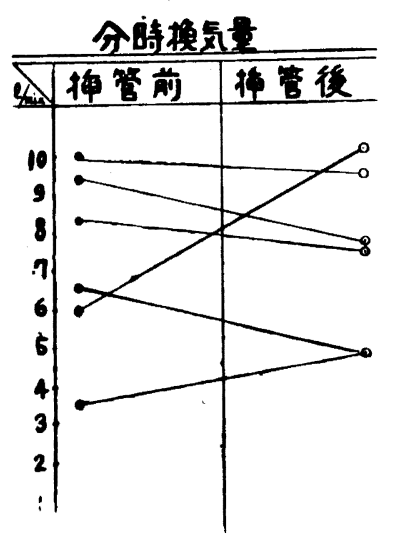

反応である息耐え反射，检反射，気管支痙等 一連の Vago respiratory response として考 えられる。

図表[2]次に酸素利用率はやや増加する か，之は換気量低下に伴 5代供性作用によるる のであろ 5 。

図表[3]此の結果, 酸素消韯量も少しく增 加している。

*曼大外科 ** 曼大内科 